\title{
A SARS-CoV-2-pandémia hatása a vérkészítmény-felhasználásra a Pécsi Tudományegyetemen
}

\author{
Pál Sándor dr. ${ }^{1}$ - Réger Barbara dr. ${ }^{2}$ - Kiss Tamás dr. ${ }^{3}$ \\ Alizadeh Hussain dr. ${ }^{4}$. Vereczkei András dr. ${ }^{5}$. Miseta Attila dr. ${ }^{2}$ \\ Szomor Árpád dr. ${ }^{4}$ - Faust Zsuzsanna dr. ${ }^{1}$ \\ ${ }^{1}$ Pécsi Tudományegyetem, Általános Orvostudományi Kar, Klinikai Központ, \\ Laboratóriumi Medicina Intézet, Transzfuziológiai Tanszék, Pécs \\ ${ }_{2}^{2}$ Pécsi Tudományegyetem, Általános Orvostudományi Kar, Klinikai Központ, Laboratóriumi Medicina Intézet, \\ Pécs \\ ${ }^{3}$ Pécsi Tudományegyetem, Általános Orvostudományi Kar, Klinikai Központ, \\ Aneszteziológiai és Intenzív Terápiás Intézet, Pécs \\ ${ }^{4}$ Pécsi Tudományegyetem, Általános Orvostudományi Kar, Klinikai Központ, \\ I. Belgyógyászati Klinika, Hematológiai Tanszék, Pécs \\ ${ }^{5}$ Pécsi Tudományegyetem, Általános Orvostudományi Kar, Klinikai Központ, Sebészeti Klinika, Pécs
}

\begin{abstract}
Bevezetés: A COVID-19-világjárvány betegellátásra gyakorolt hatása hazánkban is jelentős. A vérellátást nehezítette a járványügyi intézkedések következményeként a véradási események elmaradása, a csökkent véradási hajlandóság, továbbá a nehezen megítélhető vérkészítményigény . A „Patient Blood Management” irányelveinek az orvosi gyakorlatban történő egyre szélesebb körű alkalmazása elősegíti az optimális vérkészítmény-felhasználást a transzfúziók lehetôség szerinti elkerülésével.

Célkitüzés és módszer: Vizsgálatunk célja a Pécsi Tudományegyetem Klinikai Központjának Janus Pannonius Klinikai Tömbjében a vérkészítmény-felhasználás változásainak felmérése volt a 2020. év első öt hónapjában.

Eredmények: A járványügyi intézkedéseket követő időszakban szignifikánsan csökkent a hospitalizált betegeknek (34,08\%), a transzfúziót igénylő betegeknek (39,69\%) és a felhasznált vörösvérsejt-készítményeknek (46,41\%) a száma, valamint az egy betegre jutó felhasznált vörösvérsejt-koncentrátum átlaga (2,61-ről 1,97-re) is. Közel 30\%-os arányban csökkent a felhasznált friss fagyasztott plazma egységeinek és a thrombocytakoncentrátumoknak a száma is. Következtetés: A szigorú korlátozások életbe léptetését követően a nehézségek ellenére sikerült elegendő mennyiségú vérkészítményt biztosítani a betegeknek. Az Országos Vérellátó Szolgálat Pécsi Regionális Vérellátó Központja munkatársainak és a klinikusok erőfeszítéseinek köszönhetően a vérkészítményigény és -kínálat között új egyensúly alakult ki, mely megfelelő ellátást biztosított a feltétlenül szükséges transzfúziók kivitelezéséhez.

Orv Hetil. 2021; 162(43): 1717-1723.
\end{abstract}

Kulcsszavak: Patient Blood Management, vérkészítmény-felhasználás, koronavírus-világjárvány

\section{Effect of SARS-CoV-2 pandemic on blood product usage at the University of Pécs}

Introduction: The impact of COVID-19 pandemic on patient care is pronounced also in Hungary. Blood supply was hindered by the reduction of public blood donation events, the reduced willingness to donate, and the difficult predictability of blood product demand as a result of the epidemiological regulations. The wider application of Patient Blood Management guidelines in the medical practice will promote optimal blood product utilization by avoiding transfusions where possible.

Objective and method: The aim of our study was to assess the changes in the usage of blood products in the first five months of 2020 at the Clinical Center of the University of Pécs, Janus Pannonius Clinical Building.

Results: In the period following the epidemiological measures, we found reduction in the number of hospitalized patients $(34.08 \%)$, in the number of patients requiring transfusion $(39.69 \%)$ and in the number of red blood cell products used $(46.41 \%)$. The number of transfused red blood cell concentrates per patient was also significantly reduced (from 2.61 to 1.97 ) in this period. The number of transfused fresh frozen plasma units and platelet concentrates also decreased by approximately $30 \%$. 
Conclusion: After the implementation of the strict restrictions, despite the difficulties, it was possible to provide patients with sufficient blood products. Due to the efforts of both the Regional Blood Transfusion Center of Pécs of the Hungarian National Blood Transfusion Service and of the clinicians, a new balance was established between the demand and the supply of blood products, which provided adequate care for the necessary transfusions.

Keywords: Patient Blood Management, blood product usage, coronavirus pandemic

Pál S, Réger B, Kiss T, Alizadeh H, Vereczkei A, Miseta A, Szomor Á, Faust Zs. [Effect of SARS-CoV-2 pandemic on blood product usage at the University of Pécs]. Orv Hetil. 2021; 162(43): 1717-1723.

(Beérkezett: 2021. június 14.; elfogadva: 2021. július 26.)

\begin{abstract}
Rövidítések
COVID-19 = (coronavirus disease 2019) koronavírus-betegség 2019; FFP = friss fagyasztott plazma; JPKT = Janus Pannonius Klinikai Tömb; OVSZ = Országos Vérellátó Szolgálat; PBM = (Patient Blood Management) hazai adaptációja a Nemzeti Véradó és Vérmentő Program; PTE KK = Pécsi Tudományegyetem, Klinikai Központ; RNS = ribonukleinsav; SARS-CoV-2 $=$ (severe acute respiratory syndrome coronavirus 2) súlyos akut légúti tünetegyüttest okozó koronavírus-2; SD = standard deviáció
\end{abstract}

A transzfúziós beavatkozás egyre biztonságosabbá vált a vérrel átvihető fertőző betegségek kimutatását szolgáló, mind érzékenyebb szúrővizsgálatok bevezetésével, a vérkészítmény-elóállítás és a vértárolás fejlődésével [1]. Az új kórokozók azonban jelentős veszélyforrásai lehetnek a transzfúziónak, mivel a rutinszerúen alkalmazott szürővizsgálatokkal nem mutathatók ki. Ezek potenciálisan vérrel terjedő kórokozóknak tekintendők, amíg tudományos bizonyíték nem támasztja alá ennek ellenkezőjét [2, 3]. Új kórokozók megjelenésekor a vírus terjedését akadályozó módszerek bevezetése indokolt. Az utóbbi két évtizedben a Chikungunya-, a Zika- és a 'West Nile'-vírus felbukkanása esetében az ezek transzfúzióval történő terjedését gátló intézkedésekre is szükség volt [4-7].

A 2020-as évet nagymértékben meghatározó, új típusú koronavírus okozta pandémia hazánkra is komoly hatást gyakorolt. A 'severe acute respiratory syndrome coronavirus 2' (SARS-CoV-2) elnevezésú vírus általi megfertőződés akár súlyos, életet veszélyeztető, felső és alsó légúti megbetegedés kialakulásához vezethet, mely az Egészségügyi Világszervezet (World Health Organization - WHO) ajánlásainak megfelelően a COVID-19 elnevezést kapta [8]. Világszerte, így Magyarországon is rendkívüli intézkedések voltak szükségesek a járvány terjedésének lassítására a korábbi járványok (például SARS, influenzavírusok okozta járványok) során szerzett tapasztalatok és a legfrissebb, a COVID-19-járvánnyal kapcsolatos korai adatok alapján. A speciális rendeletek a szakrendelések és elektív sebészeti beavatkozások időszakos leállása mellett az intenzív terápiás ellátásban is jelentős változásokat eredményeztek a COVID-19 intenzív ellátására való felkészülés következtében $[9,10]$.
A rendkívüli helyzet a vérellátásra is jelentős hatást gyakorolt. A donációs hajlandóság csökkenése miatt fel kellett készülni a vérkészlet várható csökkenésére is, és biztosítani kellett a vérellátás biztonságosságát [11]. Az új típusú koronavírus kapcsán elsőként végzett vizsgálatok arra utaltak, hogy a fertőzöttek 15\%-ánál a vérből is kimutatható volt a vírus. Bár a vírus-RNS koncentrációja ezekben az esetekben alacsony volt, a transzfúzióval történő terjedés nem volt teljes mértékben kizárható [12]. A rendelkezésre álló adatok hiányossága és bizonytalansága miatt a már ismert koronavírus-típusok által szerzett tapasztalatot kellett figyelembe venni, mely alapján a betegség vér általi terjedésének kockázata alacsony [ 8 , 13]. Ennek elhárítására elegendőnek bizonyult a véradók kérdő́vekkel történő szưrése véradás elött.

Kihívást jelentett a vérellátás szempontjából a donációs hajlandóság csökkenése és a külső helyszíneken szervezett vérgyújtési események elmaradása, melyek általában a véradások többségét biztosítják [14]. A donorok előzetes időpont-egyeztetést követően jelentkezhettek véradásra. Ideiglenesen a véradástól eltiltották azokat, akik esetében felmerült a gyanú, hogy megfertőződtek az új típusú koronavírussal az elmúlt időszakban. A nemzetközi tendenciákkal párhuzamosan a vérkészítményfelhasználás csökkenésére országunkban is számítani lehetett, ennek mértéke azonban nehezen volt megjósolható $[15,16]$. Az Országos Vérellátó Szolgálat (OVSZ) tájékoztatta a fekvőbeteg-ellátó intézeteket a véradás átszervezésének ideje alatt a vérkészítmények elérhetôségének várható átmeneti csökkenéséről. Az OVSZ adatai alapján Magyarországon a járvány első hulláma kapcsán elrendelt intézkedéseket követő időszakban a mobil véradási események száma csökkent a legjelentősebb mértékben, 61\%-kal, a véradásra megjelent donorok száma pedig $28 \%$-kal lett kevesebb. A vörösvérsejt- és plazmakészítmények felhasználása országosan 30\%-kal, a thrombocytakoncentrátum-felhasználás 20\%-kal csökkent [17].

Az elmúlt évtizedben egyre több irányelv jelent meg, amely a betegellátás során a transzfúziók lehetőség szerinti elkerülését célozza. Az ezzel kapcsolatos ajánlásokat egy új koncepció keretében foglalták össze, melyet a szakirodalomban „Patient Blood Management” (PBM) 
1. táblázat |A Patient Blood Management alappillérei

\begin{tabular}{|c|c|c|}
\hline $\begin{array}{l}\text { A haemopoesis } \\
\text { optimalizálása }\end{array}$ & $\begin{array}{l}\text { A haemostasis } \\
\text { biztosítása }\end{array}$ & $\begin{array}{l}\text { Az anaemia fiziológiás } \\
\text { toleranciájának } \\
\text { fokozása }\end{array}$ \\
\hline $\begin{array}{l}\text { Az anaemiás } \\
\text { állapotok farmakoló- } \\
\text { giai rendezése, } \\
\text { a hiányanaemiák } \\
\text { kezelése, a vérképzés } \\
\text { gyógyszeres } \\
\text { támogatása }\end{array}$ & $\begin{array}{l}\text { A vérzékenységet } \\
\text { fokozó gyógyszerek } \\
\text { körültekintő } \\
\text { alkalmazása }\end{array}$ & $\begin{array}{l}\text { A restriktív vörösvér- } \\
\text { sejt-transzfúziós } \\
\text { szemlélet lehetőség } \\
\text { szerinti előtérbe } \\
\text { helyezése }\end{array}$ \\
\hline $\begin{array}{l}\text { Anémizáló gyógy- } \\
\text { szerek körültekintő } \\
\text { alkalmazása }\end{array}$ & $\begin{array}{l}\text { A perioperatív, } \\
\text { intraoperatív } \\
\text { vérvesztés minimali- } \\
\text { zálása, vérzést } \\
\text { csökkentó módszerek } \\
\text { alkalmazása }\end{array}$ & $\begin{array}{l}\text { Az oxigén kínálat/ } \\
\text { igény arányának } \\
\text { optimalizálása }\end{array}$ \\
\hline \multirow[t]{2}{*}{$\begin{array}{l}\text { A műtétek előtt } \\
\text { autológ vér gyújtése }\end{array}$} & & $\begin{array}{l}\text { A keringésterhelés } \\
\text { csökkentése }\end{array}$ \\
\hline & & $\begin{array}{l}\text { Szigorú masszív } \\
\text { transzfúziós } \\
\text { protokoll használata }\end{array}$ \\
\hline
\end{tabular}

néven említenek [18-20]. A PBM irányelveit három csoportba rendezték, melyeket alappilléreknek neveztek el: (i) a haemopoesis optimalizálása, (ii) a haemostasis biztosítása és (iii) az anaemia fiziológiás toleranciájának fokozása (a PBM alappilléreit az 1. táblázatban részletezzük) [21-23]. Ezen alapelvek folyamatos oktatása és a klinikai gyakorlatban történő alkalmazása elősegíti a vérkészítmények hatékonyabb és biztonságosabb felhasználását a betegellátás rutinszerú múködése esetén is, ezenkívül a szerzett ismeretek és tapasztalatok még értékesebbek, ha a vérkészítmények biztosítása nehezített [1].

A Pécsi Tudományegyetem Klinikai Központjának legnagyobb telephelye a Janus Pannonius Klinikai Tömb (JPKT). A JPKT-ben múködik az Aneszteziológiai és Intenzív Terápiás Intézet, az I. Belgyógyászati Klinika (Gasztroenterológiai, Angiológiai, Hematológiai, valamint Endokrinológiai és Anyagcsere Tanszék), az Érsebészeti Klinika, a Traumatológiai és Kézsebészeti Klinika, a Sebészeti Klinika, a Sürgősségi Orvostani Tanszék, az Ortopédiai Klinika egy osztálya és a Neurológiai Klinika Stroke Osztálya. A PTE klinikáit az OVSZ Pécsi Regionális Vérellátó Központja látja el vérkészítményekkel. A JPKT klinikái számára érkező vérkészítményeket a PTE KK Transzfúziós Szolgálata fogadja és tárolja. A 2019-es év második felében a JPKT Transzfúziós Szolgálat adatai alapján az átlagos vérkészítmény-felhasználás havonta kb. 1300 egység vérkészítmény volt.

Jelen vizsgálatunkban a JPKT klinikáinak vérfelhasználását elemeztük a COVID-19-járvány magyarországi megjelenésekor bevezetett járványügyi intézkedések előtti és utáni időszakban.

\section{Anyag és módszer}

A 2020. 01. 01. és 2020. 05. 31. közötti időszak adatait dolgoztuk fel a PTE KK Transzfúziós Szolgálatának adatbázisából. Heti bontásban vizsgáltuk a hospitalizált betegeknek, a transzfúzión átesett betegeknek és a felhasznált vérkészítményeknek a számát, valamint az egy betegre jutó felhasznált vérkészítmények átlagát. 994 beteg esetén megvizsgáltuk a vörösvérsejt-koncentrátumok transzfúziója előtt mért hemoglobinértéket. Felmérésünk során két időszakot hasonlítottunk össze. A kórházi betegellátás korlátozásának hetét tekintettük a két időszak közötti határnak, melyet így vizsgálatunkból kihagytunk. Az első vizsgált időszak a járványügyi intézkedések előtt a 2020. 01. 01. és 2020. 03. 08. közötti heteket, a második időszak pedig a 2020. 03. 16. és 2020. 05. 31. közötti heteket tartalmazza. A statisztikai elemzést az SPSS 20-as verziója (IBM Corporation, Armonk, NY, USA) és a Microsoft Excel ${ }^{\mathrm{TM}}$ (Microsoft Corporation, Redmond, WA, USA) segítségével végeztük. A két időszakot t-teszttel hasonlítottuk össze, emellett az adatsorok közötti különbség mértékének becslésére a Cohenféle D-módszert alkalmaztuk. A különbség mértékét ezen módszer standard deviációban (SD) adja meg, mely kismértékû $0,3 \mathrm{SD}$ alatti, közepes mértékú $0,3-0,6 \mathrm{SD}$ közötti és nagymértékú 0,6 SD feletti érték esetében.

\section{Eredmények}

A teljes vizsgált időszakban 5558 beteg kórházi ellátására került sor. Fekvő betegeink 17,21\%-a igényelt vörösvérsejt-transzfúziót, összesen 2975 egység vörösvérsejtkoncentrátum került beadásra. Az egy betegre jutó felhasznált vörösvérsejt-koncentrátum átlaga 2,29 volt. Friss fagyasztott plazmából (FFP) 558 egység, thrombocytakoncentrátumból 470 egység került felhasználásra (1. és 2. ábra).

Az időszak két intervallumának összehasonlítása során statisztikailag szignifikáns mértékü csökkenés volt észlelhető a hospitalizált betegek $(34,08 \%, \mathrm{p}<0,0001)$ és a transzfundált betegek számában $(39,69 \%, \mathrm{p}<0,0001)$ (1. ábra, $A$ és B).

Az intézkedések bevezetését követő első négy hétben csökkent a leginkább a hospitalizációk száma, 40,82\%kal, majd később lassan emelkedő tendenciát mutatott $(\mathrm{p}=0,001)$. Hasonló mértékú csökkenés $(45,64 \%)$ volt megfigyelhető a transzfundált betegek számában $(\mathrm{p}=$ 0,001 ) (2. és 3. táblázat). Ugyancsak jelentős mértékben, $53,24 \%$-kal csökkent ebben a négy hétben a felhasznált vörösvérsejt-koncentrátumok száma $(\mathrm{p}=0,001)$ (1. ábra, F).

A felhasznált vörösvérsejt-koncentrátum mennyisége heti 176,09 $\pm 50,20(S D)$ egységről 94,36 $\pm 20,95$ (SD) egységre csökkent, és az egy betegre jutó átlagos vörösvérsejt-koncentrátum $2,61 \pm 0,44(\mathrm{SD})$ egységról $1,97 \pm$ 0,33 (SD) egységre szorult vissza. A különbség mindkét 

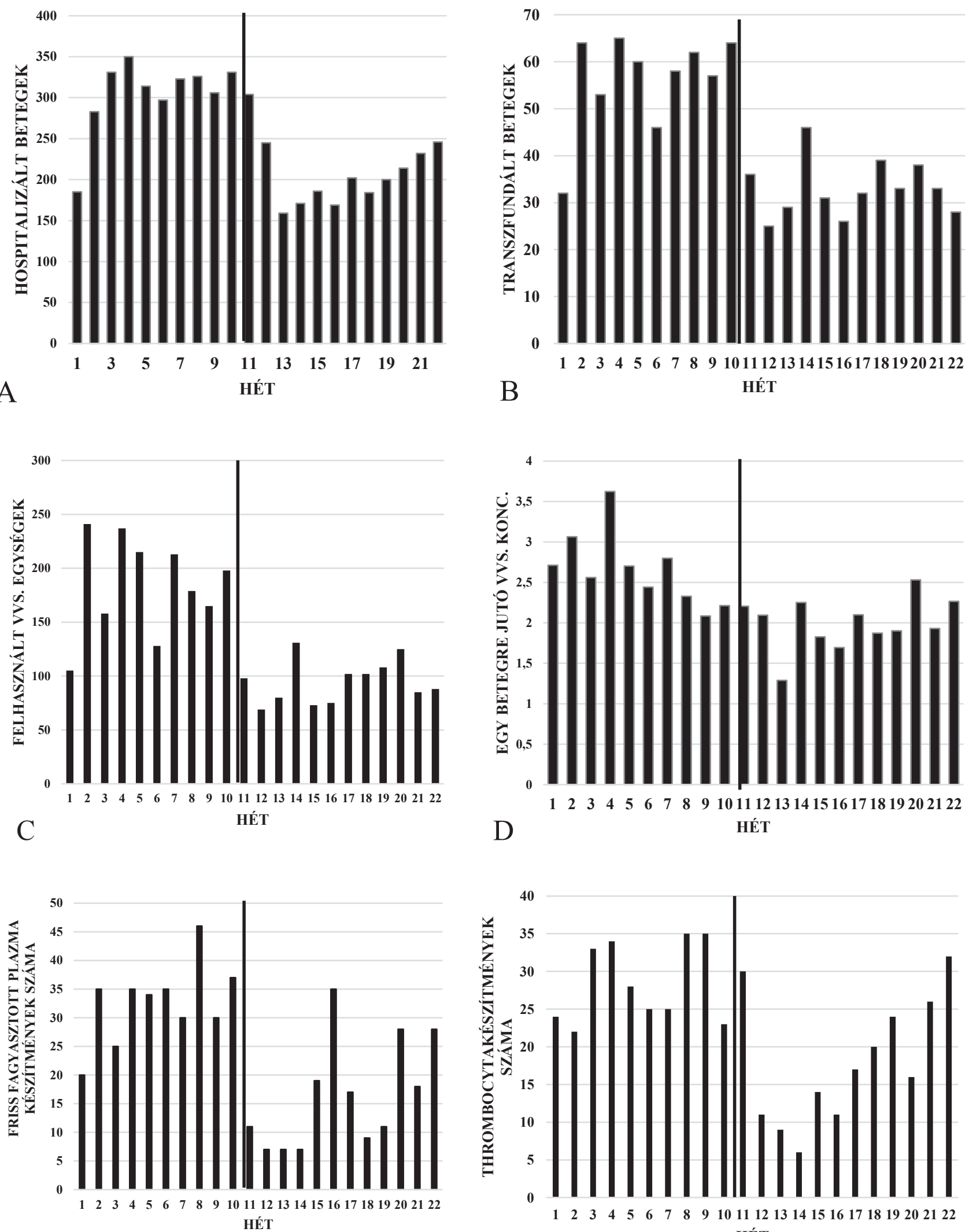

$\mathrm{E}$

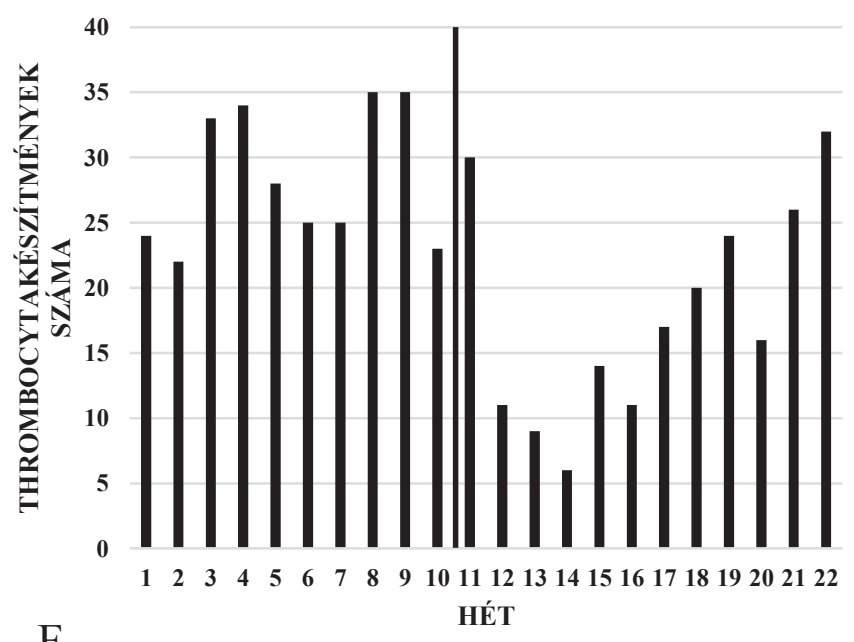

1. ábra

A vizsgált időszak két periódusa közötti különbségek a hospitalizációk (A), a transzfundált betegek száma (B), a beadott vörösvérsejt-koncentrátumok mennvisége $(\mathrm{C})$, az átlagosan egy betegre jutó felhasznált vörösvérsejt-koncentrátumok száma (D), a felhasznált friss fagyasztott plazma (E) és thrombocytakészítmények (F) szempontjából

VVS. = vörösvérsejt 
2. táblázat |A vizsgált időszakok összehasonlítása

\begin{tabular}{lllll}
\hline Klinikai Tömb & $\begin{array}{l}\text { A hospitalizált betegek } \\
\text { száma }\end{array}$ & $\begin{array}{l}\text { A transzfundált betegek } \\
\text { száma }\end{array}$ & $\begin{array}{l}\text { A felhasznált vörösvérsejt- } \\
\text { koncentrátum száma }\end{array}$ & $\begin{array}{l}\text { Átlagos vörösvérsejt-kon- } \\
\text { centrátum betegenként }\end{array}$ \\
\hline Heti átlag - első időszak & $304,55 \pm 43,78(\mathrm{SD})$ & $54,27 \pm 11,48(\mathrm{SD})$ & $176,09 \pm 50,20(\mathrm{SD})$ & $2,61 \pm 0,44(\mathrm{SD})$ \\
\hline Heti átlag - második időszak & $200,73 \pm 30,48(\mathrm{SD})$ & $32,72 \pm 6,23(\mathrm{SD})$ & $94,36 \pm 20,95(\mathrm{SD})$ & $1,97 \pm 0,33(\mathrm{SD})$ \\
\hline p-Érték & 0,0001 & 0,0001 & 0,0001 & 0,0010 \\
\hline Összesített & $5558(100 \%)$ & $957(100 \%)$ & $2975(100 \%)$ & 2,29 \\
\hline Első időszak - összes & $3350(60,27 \%)$ & $597(62,38 \%)$ & $1937(65,10 \%)$ & 2,61 \\
\hline Második időszak - összes & $2208(39,72 \%)$ & $360(37,61 \%)$ & $1038(34,89 \%)$ & 1,97 \\
\hline A csökkenés mértéke & $34,08 \%$ & $39,69 \%$ & $46,41 \%$ & $24,52 \%$ \\
\hline
\end{tabular}

SD = standard deviáció

3. táblázat |Az első időszak utolsó négy hetének összehasonlítása a második időszak első négy hetével

\begin{tabular}{lllll}
\hline & $\begin{array}{l}\text { A hospitalizált betegek } \\
\text { száma }\end{array}$ & $\begin{array}{l}\text { A transzfundált betegek } \\
\text { száma }\end{array}$ & $\begin{array}{l}\text { A felhasznált vörösvérsejt- } \\
\text { koncentrátum száma }\end{array}$ & $\begin{array}{l}\text { Átlagos vörösvérsejt- } \\
\text { koncentrátum betegenként }\end{array}$ \\
\hline Az első idószak utolsó négy hete & $321,5 \pm 1084$ & $60,25 \pm 3,30$ & $188,75 \pm 21,07$ & $2,35 \pm 0,31$ \\
\hline A második időszak első négy hete & $190,25 \pm 38,13$ & $32,75 \pm 9,17$ & $88,25 \pm 28,86$ & $1,86 \pm 0,42$ \\
\hline p-Érték & 0,001 & 0,001 & 0,001 & 0,11 \\
\hline A csökkenés aránya & $40,82 \%$ & $45,64 \%$ & $53,24 \%$ & $20,85 \%$ \\
\hline
\end{tabular}

esetben statisztikailag jelentős ( $\mathrm{p}=0,0010$, valamint $\mathrm{p}<0,0001$ ) (1. ábra, C és D).

A felhasznált FFP mennyisége a két időszakban heti bontásban átlagosan 32,70 \pm 7,05 (SD) vs. 21,00 $\pm 15,6$ (SD) egység volt (1. ábra, E). A vizsgált időszak két intervallumában az egy betegre jutó felhasznált FFP 2,61 \pm 0,72 (SD) egységről 2,99 $\pm 1,08$ (SD ) egységre változott.

A thrombocytakoncentrátumok felhasználása hasonló mértékben csökkent, 28,40 $\pm 5,29$ (SD) vs. 16,91 $\pm 7,94$ (SD) készítmény a két időszakban (1. ábra, F). Az egy betegre számított felhasználásuk 2,32 $\pm 0,46(\mathrm{SD})$ készítményról 1,94 \pm 031 (SD) készítményre módosult.

A hetente felhasznált FFP- és thrombocytakészítmények száma szignifikánsan csökkent a második időszakban ( $\mathrm{p}=0,0008$ és $\mathrm{p}=0,0022)$, az egy betegre jutó felhasználás azonban egyik készítmény vonatkozásában sem változott szignifikánsan ( $\mathrm{p}=0,4144$ és $\mathrm{p}=0,2580)$.

A két időszakban vizsgált 994 beteg transzfúzió előtti hemoglobinértékében is szignifikáns csökkenést találtunk. Az első időszakban 632 betegnél átlagosan 73,59 $\pm 12,88 \mathrm{~g} / 1$, míg a második időszakban 362 betegnél $69,69 \pm 13,02 \mathrm{~g} / 1$ volt a transzfúzió előtti hemoglobinérték $(\mathrm{p}<0,0001)$.

A Cohen-féle D-módszerrel a hospitalizációk, a transzfundált betegek, a felhasznált vérkészítmények számának és az egy betegre jutó vörösvérsejt-koncentrátumnak az átlaga is nagymértékű különbséget mutatott a két vizsgált időszak összehasonlításakor (1,44 felett). A transzfúzió előtti átlagos hemoglobinértékek közepes mértékben csökkentek a második periódusban.

\section{Megbeszélés}

A COVID-19-világjárvány rendkívüli helyzetet teremtett az orvosi gyakorlatban a világon és hazánkban is. A folyamatos, hatékony és biztonságos betegellátás érdekében meghozott járványügyi intézkedések érintették a vérgyújtést és a vérfelhasználást is [8]. Az OVSZ a rendelkezéseknek megfelelően járványmegelőző, a vírus terjedését mérséklő szabályokat rendelt el intézményeiben. A donációs hajlam csökkenése mellett a vérfelhasználás is csökkenő tendenciát mutatott hazánkban [17].

Felmérésünk során a vérkészítmény-felhasználás változásait vizsgáltuk a JPKT klinikáin a 2020. év első öt hónapjában.

A hospitalizált betegek száma a járványügyi intézkedések bevezetése után közel egyharmad résszel csökkent. A vizsgált időszakban a COVID-19-betegségben szenvedő betegek száma nem indokolta, hogy a JPKT osztályain is kezeljenek SARS-CoV-2-fertőzött betegeket, így a beteganyag változását elsősorban az akut, nem halasztható ellátás előtérbe kerülése okozta az elektív ortopédiai, sebészeti és érsebészeti mútétek átmeneti elmaradásával. A hospitalizált betegek számának csökkenése főleg a rendeletek életbe lépését követő 4-5 hétben kifejezettebb, ezt követően kisebb mértékü emelkedő tendencia figyelhető meg, mivel a kedvező járványügyi helyzetben felvételre kerültek a korábban halasztott, de mielőbbi ellátást igénylő, sürgőssé váló esetek.

A második időszakban jelentősen alacsonyabb volt a transzfundált betegek száma is. A vérkészítmények közül mind a vörösvérsejt-koncentrátumnak, mind a thrombo- 

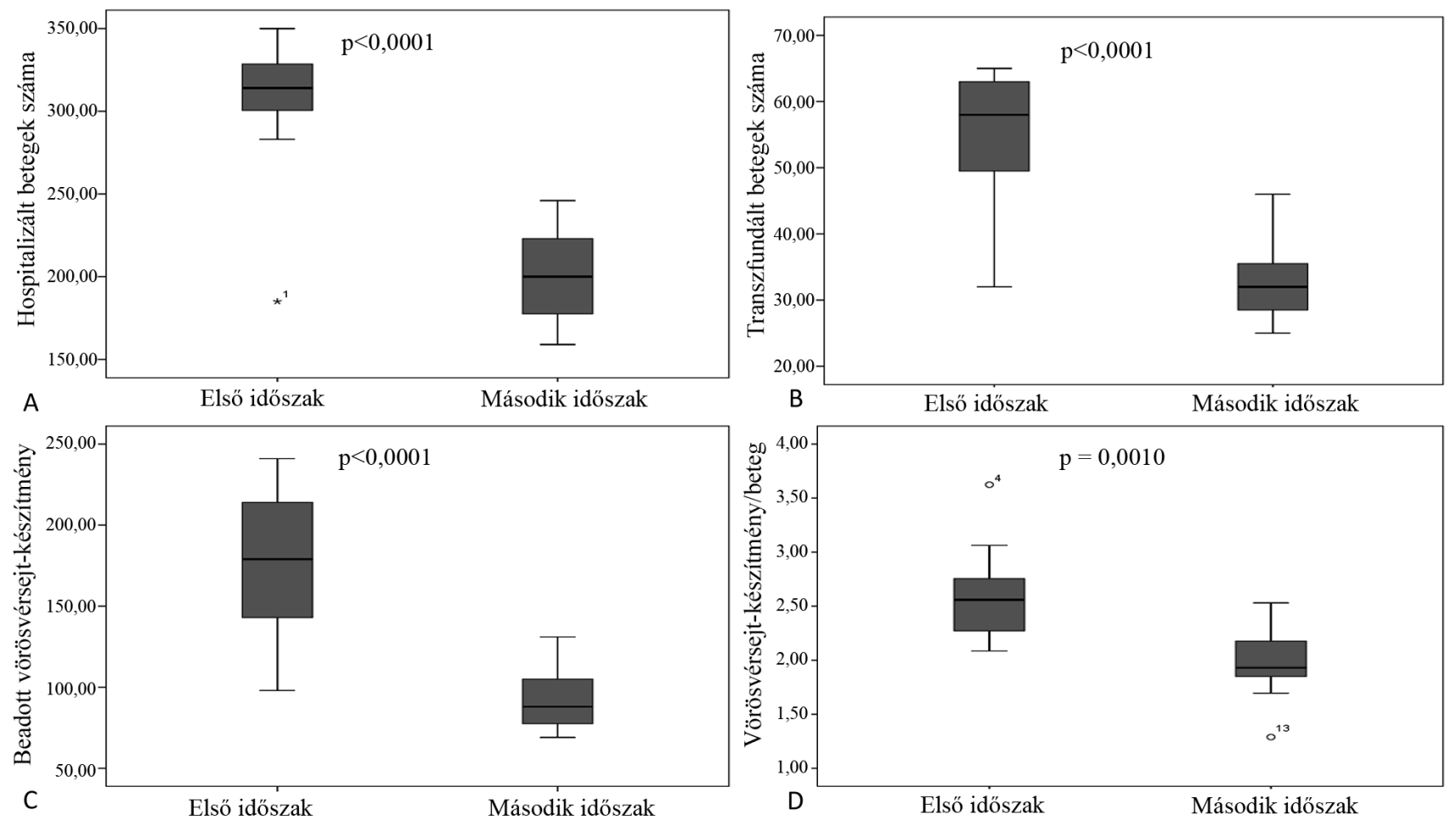

2. ábra

| A betegeknek és a transzfúzióban részesülóknek, valamint a vörösvérsejt-készítményeknek a felhasználási adatai a vizsgált időszakokra vonatkozóan

cytakoncentrátumnak és az FFP-egységeknek a felhasználása jelentősen csökkent. A legnagyobb mértékben a felhasznált vörösvérsejt-koncentrátumok száma csökkent, közel 50\%-ban. Ez egyrészt az alacsonyabb betegszámmal, másrészt az átlagosan egy betegre jutó felhasznált vörösvérsejt-koncentrátumok számának csökkenésével magyarázható. A vizsgált időszak utolsó heteire jellemző, emelkedő tendenciát mutató hospitalizációk ellenére a transzfundált betegeknek és a felhasznált vörösvérsejt-készítményeknek a száma csak enyhe változásokat mutatott ebben az időszakban.

A járványügyi intézkedéseket követően az egy beteg ellátása során felhasznált vérkészítmények számának emelkedése volt várható, ugyanis ideiglenesen csak a halaszthatatlan, életveszélyes állapotban levő betegek ellátására volt lehetôség. Ezen betegek ellátása általában nagyobb vérkészítményigénnyel jár. A Sebészeti Klinikán az akut mütéti beavatkozást igénylő páciensek kerültek ellátásra, esetükben nincs lehetőség az anaemia preoperatív, nem transzfúzióval történő kezelésére. A traumatológiai betegek és a különböző alapbetegségek következményeként jelentkező tápcsatornai vérzéses, gasztroenterológiai páciensek transzfúziós igénye változatlanul fennállt. A hematológiai betegek ellátása betegségük jellegéból adódóan ritkán halasztható, így a transzfúziós igény jelentős csökkenése ezen a területen sem volt várható.

Vizsgálatunk adatai ugyanakkor azt tükrözik, hogy az egy betegre jutó, átlagosan felhasznált vörösvérsejt-koncentrátumok száma a járvány kitörése után közel egynegyedével csökkent. Ehhez valószínúleg hozzájárult a PBM-szemlélet korábban elkezdett alkalmazása, mely az utóbbi években a PTE KK vérkészítményítmény-felhasználásának jelentős csökkenését tette lehetővé, és amely még inkább érvényesült a járványhelyzet során. A PBM ajánlásai közül elsősorban a restriktív transzfúziós elvek kerültek előtérbe, melyek helyesen alkalmazva fokozzák a betegellátás biztonságosságát, és elősegítik a feltétlenül szükséges transzfúziók biztosítását. Eredményeink szerint a betegek a járványügyi intézkedések előtt átlagosan a restriktív vérfelhasználásra való törekvésnek megfelelő hemoglobinérték esetén kaptak vörösvérsejt-transzfúziót, míg a vizsgálat második időszakában ez az érték még alacsonyabb volt. Amennyiben a beteg állapota szükségessé tette, ennél magasabb értéknél is biztosított volt számára a transzfúzió lehetősége. A restriktív transzfúziós indikáció mellett az intravénás és per os vaskészítmények és az orrszondán keresztül alkalmazott oxigénterápia gyakoribb alkalmazása is hozzájárult a vérkészítmény-felhasználás csökkentéséhez, fokozva a beteg haemopoesisét és az anaemiás állapot toleranciáját. A haemostasis célzott kezelésének lehetôségét biztosította a JPKT területén elérhető 'point-of-care' (műtőasztal/betegágy melletti) thromboelastographiás vizsgálatok alkalmazása.

A thrombocyta- és FFP-készítmények felhasználása is jelentősen csökkent a járványügyi intézkedések bevezetését követően. Az FFP-készítmények elérhetősége nem változott, mivel a véradásokból származó FFP jelentős része nem kerül közvetlenül transzfúzióra, hanem plazmaderivátumok előállításának alapanyagát képezi. A járvány hatására a vizsgált 5 hónapos időszakban az FFP betegenkénti átlagos felhasználása nem változott. A thrombocytakoncentrátumok elérhetősége rövid lejára- 
tuk miatt jobban függ a véradások számától, de ennél a készítménynél sem volt szükség a korábbinál szigorúbb indikációk bevezetésére a járvány miatt.

A kivételesen nehéz, kihívásokkal teli helyzetben az OVSZ munkatársai és a klinikusok közötti szoros együttmúködéssel, valamint a PBM elveinek figyelembevételével sikerült biztosítani a feltétlenül szükséges transzfúziók kivitelezéséhez a vérkészítményeket.

\section{Következtetés}

A hazánkban is megjelent új típusú koronavírus okozta világjárvány drasztikus változásokhoz vezetett a betegellátásban, így a vérellátás területén is. A vérellátás és a vérfelhasználás szempontjából is kihívást jelentő időszakban a megszokott módszerek újragondolására volt szükség a biztonságos betegellátás biztosításához. A nehézségek ellenére új egyensúly alakult ki a vérigény és a vérkészítmény-kínálat között, aminek következtében a feltétlenül szükséges transzfúziók biztosítottak voltak.

Anyagi támogatás: A közlemény megírása, valamint a kapcsolódó tevékenység anyagi támogatásban nem részesült.

Szerzői munkamegosztás: P. S.: Adatgyüjtés, adatfeldolgozás, az eredmények értékelése, a közlemény megírása. R. B.: Adatfeldolgozás, módszertani leírás, az eredmények értékelése, a közlemény megírása. K. T., Sz. Á.: Az eredmények értékelése. F. Zs., M. A., A. H., V. A.: Az eredmények értékelése, a közlemény megírása. A cikk végleges változatát valamennyi szerző elolvasta és jóváhagyta.

Érdekeltségek: A szerzőknek nincsenek érdekeltségeik.

\section{Irodalom}

[1] Spahn DR, Moch H, Hofmann A, et al. Patient Blood Management: the pragmatic solution for the problems with blood transfusions. Anesthesiology 2008; 109: 951-953.

[2] Hofmann A, Farmer S, Shander A. Five drivers shifting the paradigm from product-focused transfusion practice to Patient Blood Management. Oncologist 2011; 16(Suppl 3): 3-11.

[3] Franchini M, Marano G, Veropalumbo E, et al. Patient Blood Management: a revolutionary approach to transfusion medicine. Blood Transfus. 2019; 17: 191-195.

[4] Appassakij H, Silpapojakul K, Promwong C, et al. The potential impact of Chikungunya virus outbreaks on blood transfusion. Transfus Med Rev. 2020; 34: 23-28.

[5] Brouard C, Bernillon P, Quatresous I, et al. Estimated risk of Chikungunya viremic blood donation during an epidemic on Reunion Island in the Indian Ocean, 2005 to 2007. Transfusion 2008; 48: 1333-1341.

[6] Pisani G, Cristiano K, Pupella S, et al. West Nile virus in Europe and safety of blood transfusion. Transfus Med Hemother. 2016; 43: 158-167.
[7] Marano G, Pupella S, Vaglio S, et al. Zika virus and the neverending story of emerging pathogens and transfusion medicine. Blood Transfus. 2016; 14: 95-100.

[8] Stanworth SJ, New HV, Apelseth TO, et al. Effects of the COVID-19 pandemic on supply and use of blood for transfusion. Lancet Haematol. 2020; 7: e756-e764.

[9] Fülesdi B, Sárkány P, Szentkereszty Z, et al. Challenges of intensive care and anesthesiology related to COVID-19 pandemic: Practical considerations. [Az aneszteziológiai és intenzív ellátás kihívásai a COVID-19-fertőzéssel kapcsolatban. Gyakorlati ajánlás.] Orv Hetil. 2020; 161: 652-659. [Hungarian]

[10] Végh T, László I, Juhász M, et al. Practical aspects of anesthetic and perioperative care for COVID-19 patients. [A COVID-19fertőzött betegek anesztéziájának és perioperatív ellátásának gyakorlati szempontjai.] Orv Hetil. 2020; 161: 692-695. [Hungarian]

[11] Al Mahmasani L, Hodroj MH, Finianos A, et al. COVID-19 pandemic and transfusion medicine: the worldwide challenge and its implications. Ann Hematol, 2021; 100: 1115-1122.

[12] Mascaretti L, De Angelis V, Berti P. The severe acute respiratory syndrome coronavirus 2 (SARS-CoV-2) pandemic and transfusion medicine: reflections from Italy. Blood Transfus. 2020; 18: 77-78.

[13] Chang L, Zhao L, Gong H, et al. Severe acute respiratory syndrome coronavirus 2 RNA detected in blood donations. Emerg Infect Dis. 2020; 26: 1631-1633.

[14] Kiely P, Hoad VC, Seed CR, et al. Severe acute respiratory syndrome coronavirus-2: implications for blood safety and sufficiency. Vox Sang. 2021; 116: 155-166.

[15] Grandone E, Mastroianno M, Caroli A, et al. Blood supply and transfusion support in southern Italy: findings during the first four weeks of the SARS-CoV-2 pandemic. Blood Transfus. 2020; 18: 230-232.

[16] Wang Y, Han W, Pan L, et al. Impact of COVID-19 on blood centres in Zhejiang province China. Vox Sang. 2020; 115: 502506.

[17] Tordai A, Nagy S, Baróti-Tóth K, et al. Effects of the SARS CoV-2 pandemic on Hungarian blood banking. [A SARS-CoV2-járvány hatása a hazai vérellátásra.] Hematol Transzfuziol. 2020; 53: 96-105. [Hungarian]

[18] Goodnough LT, Shander A. Patient Blood Management. Anesthesiology 2012; 116: 1367-1376.

[19] Babik B, Fazakas J, Matusovits A, et al. Forced steps for making improvements in severe perioperative haemorrhage. [Lépéskényszerben - új feladatok az életveszélyes perioperatív vérzések ellátásában.] Orv Hetil. 2019; 160: 203-213. [Hungarian]

[20] Babik B, Fazakas J, Matusovits A, et al. Perioperative patient blood management: common risk, common tasks, common responsibility. [Perioperatív vérfelhasználás: közös kockázat, közös feladatok, közös felelősség.] Orv Hetil. 2020; 161: 1545-1553. [Hungarian]

[21] Isbister JP. The three-pillar matrix of Patient Blood Manage ment. ISBT Sci Ser. 2015; 10(S 1): 286-294.

[22] Retteghy TA. Perioperative Patient Blood Management. [A vértakarékos betegellátás a perioperatív szakban.] Hematol Transzfuziol. 2018; 51: 194-202. [Hungarian]

[23] Smudla A, Fülesdi B, Babik B, et al. National Blood Donation and Blood Saving Program in Hungary. Further steps are required to improve patient safety. [A Nemzeti Véradó és Vérmentő program helyzete Magyarországon. További lépések szükségesek a betegbiztonság fokozásához.] Orv Hetil. 2020; 161: 16061616. [Hungarian]

(Réger Barbara dr., Pécs, Ifjúság útja 13., 7624; e-mail: reger.barbara@pte.hu)

A cikk a Creative Commons Attribution 4.0 International License (https://creativecommons.org/licenses/by/4.0/) feltételei szerint publikált Open Access közlemény. (SID_1) 